\title{
Social interactions in the public space in the context of public confidence
}

\author{
Andrzej Borowski \\ Department of Sociology and Social Works, Faculty of Education and Philosophy, \\ Pomeranian University in Slupsk, 64 Westerplatte St., 76-200 Słupsk, Poland \\ E-mail address: aubor@poczta.onet.pl
}

\begin{abstract}
Without confidence, without conviction that another person can be trusted, it is not possible to function well, neither in places associated with private life nor public ones. In this study, special attention has been given to the issues of public confidence as a context of social interactions taking place in public places. Confidence is also indispensable in the sphere of activities in public places and local communities, as well as with different types of interactions. But confidence increases also a co-operation and the latter affects an increase in the level of confidence. Adherence to cultural rules, as far as the question of confidence is concerned, on the basis of inertia is of dysfunctional nature in the aspect of society as a whole. Definitely greater confidence is generated by the society being fully democratic, with the established traditions in this regard.
\end{abstract}

Keywords: public confidence; post-communist countries; social interaction; public space; social change

\section{INTRODUCTION}

Public confidence is closely related to the phenomenon of social change taking place in Central and Eastern Europe for more than twenty years. P. Sztompka, a reputed investigator of public confidence problems, has yet noted that:

"(...) the sphere of uncertainty, risk and threats undergoes a sudden enlargement, while non-transparency of structures and organisations increases (...) All that undermines the sense of existential security and social order and, as a result, generates a crisis of confidence, both horizontally - to other people, and vertically - to public institutions, leading to the culture of cynicism" [Sztompka, P. 1997.].

Without confidence, without conviction that another person can be trusted, it is not possible to function well, neither in places associated with private life nor public ones. As the results of recent studies on confidence in social life have shown, the Poles are fairly distrustful. Only about "one fourth of those questioned (23\%) assume that most people can be trusted, whereas almost three fourth (74\%) hold the principle to exercise far-reaching caution in relations with other people." [Cybulska, A. 2012]. 
That principle induces a mistrust towards values and institutions and interactions being taken in public places as well as any actions which increase the isolation in society at the cost of transparency, inducing a negative social perception [Borowski, A. 2013; Powell, 2014; Vlăduțescu, 2014; Oprea-Valentin Buşu, 2014; Iorgulescu, 2014].

\section{RESULTS OF THE STUDY ON PUBLIC CONFIDENCE AND INTERACTIONS IN PUBLIC PLACES AMONG UNIVERSITY STUDENTS}

In 2009-2012, while taking part in an international research project on the perception of public confidence categories in the post-communist countries, I gave a special attention to the issues of public confidence as a context of social interactions taking place in public places. This study involved university students from Russia (European part), Ukraine, Lithuania, the Czech Republic, the Buryat Republic (Asian part of Russia) and Poland. Within the project, about 5 thousand responders was surveyed, using a proprietary research tool (questionnaires). Confidence is the basis of co-operation and an element which holds each civil society together.

It allows citizens to solve problems and achieve social goals in a more optimal manner, with a considerably smaller input of efforts and resources. Confidence is also indispensable in the sphere of actions in public places and local communities, as well as with different types of interactions. But confidence increases also a co-operation and the latter affects an increase in the level of confidence. Then, a so called feedback follows. As opposed to financial inputs, confidence is a "moral resource", the amount of which increases the more it is being used, while disappears when being unused.

Human behaviour in public places is related to the presence of other people in the same space-time. When examining that type of human behaviour, E. Goffman focused on three basic units being interactive unity: face engagement, social occasions and public gatherings. In the presence of other people, individuals go by a specific set of rules which were called situational conventions by Goffman. Conventional or unconventional behaviour largely depends on confidence with which an individual trusts the social surroundings in a particular public place [Goffman, E. 2012].

In the study of social interactions, an individual can occur in different manners. The most known ones include so called movement module and participation module. The movement module is a human-operated specific armour (e.g. legal provisions, transportation routes) to increase the safety in public places.

The participation module, occurring in the form of a single individual and a group (at least two individuals), informs the social surroundings about the condition of a person during a day. Participation modules are related to the type of activity being taken by a man in public places: everyday route, service visit or expedition. Expedition is of sporadic nature, whereas the two other forms occur every day [Goffman, E. 2011].

During the study, within the project being described here, responders were questioned about all of the activity types being listed, using specific examples. 
Table 1. Normally, I meet more good people than bad people.

\begin{tabular}{|c|c|c|c|c|c|}
\hline Degree of agreement (\%) & $\begin{array}{c}\text { Czech } \\
\text { Republic }\end{array}$ & Lithuania & Russia & Ukraine & Poland \\
\hline Strongly disagree & 3.4 & 3.3 & 4.9 & 4.6 & 3.3 \\
\hline Disagree somewhat & 6.3 & 8.9 & 9.6 & 12.4 & 10.1 \\
\hline Hard to say & 37.6 & 20.5 & $22.2 \S$ & 25.8 & 17.2 \\
\hline Agree somewhat & 36.4 & 49.6 & 44.6 & 39.7 & 39.7 \\
\hline Strongly agree & 16.3 & 17.1 & 17.7 & 15.9 & 29.6 \\
\hline
\end{tabular}

Source: Own study within the State Committee for Scientific Research project, No. N N116438837

The highest percentage of answers referring to positive evaluation of people being met in public places has been declared by responders from Poland, while the least one by those from the Czech Republic. Relatively speaking, the level of confidence in the people being met is high among responders. This may be due to the young age and education of responders. Previous studies have confirmed a decline in confidence together with age and lower level of education [Cybulska, A. 2012].

Table 2. There is no room for confidence in business activity.

\begin{tabular}{|c|c|c|c|c|c|}
\hline Degree of agreement (\%) & $\begin{array}{c}\text { Czech } \\
\text { Republic }\end{array}$ & Lithuania & Russia & Ukraine & Poland \\
\hline Strongly disagree & 11.5 & 5.8 & 4.8 & 5.8 & 11.1 \\
\hline Disagree somewhat & 31.7 & 26.1 & 17.5 & 18.3 & 27.5 \\
\hline Hard to say & 28.3 & 32.5 & 31.5 & 31.1 & 25.8 \\
\hline Agree somewhat & 22.6 & 25.1 & 27.6 & 24.5 & 23.2 \\
\hline Strongly agree & 5.8 & 10.1 & 17.1 & 18.0 & 12.3 \\
\hline
\end{tabular}

Source: Own study within the State Committee for Scientific Research project, No. N N116438837

The social surroundings have been given the greatest confidence in business activity among the Czechs, while the least one among Russians. The highest percentage of distrustful attitudes are displayed by responders from the countries of the former Soviet Union due to gradually occurring evolution of the economic system. Responders from the Czech Republic and Poland, due to the established legal system and centuries-old traditions, trust the social surroundings relatively more as concerns business issues. This regularity has been also observed by A. Cybulska who has stated that the market economy apparently serves confidence development in business well. Since 2002, i.e. since we have been studying the opinions of interviewees on that topic, the percentage of responders recognising the principle of limited confidence in other people in this sphere has been regularly decreasing, while the number of those who think that confidence in business is profitable has increased. Therefore, the old 
argument that confidence is a particularly valuable asset in business if you want to operate over a longer period of time [Cybulska, A. 2012].

Table 3. Employers put employee's good last.

\begin{tabular}{|c|c|c|c|c|c|}
\hline Degree of agreement (\%) & $\begin{array}{c}\text { Czech } \\
\text { Republic }\end{array}$ & Lithuania & Russia & Ukraine & Poland \\
\hline Strongly disagree & 4.2 & 2.0 & 3.2 & 3.7 & 11.1 \\
\hline Disagree somewhat & 26.9 & 18.6 & 13.8 & 12.4 & 25.5 \\
\hline Hard to say & 35.6 & 31.3 & 27.4 & 27.9 & 25.6 \\
\hline Agree somewhat & 28.6 & 36.8 & 37.9 & 33.5 & 25.2 \\
\hline Strongly agree & 4.4 & 11.3 & 16.1 & 19.8 & 12.5 \\
\hline
\end{tabular}

Source: Own study within the State Committee for Scientific Research project, No. N N116438837

Confidence in proper treatment by the employer has been showed relatively to the highest extent by responders from Poland, while those from the former Soviet republics have assessed their employers the worse. This is due to the model of labour relations being preferred through many decades where the work collective's good was the most important instead of that of a single employee, as well as the state's success and welfare instead of that of an individual.

Table 4. I believe that people asking in the street for financial help do not cheat me.

\begin{tabular}{|c|c|c|c|c|c|}
\hline Degree of agreement (\%) & $\begin{array}{c}\text { Czech } \\
\text { Republic }\end{array}$ & Lithuania & Russia & Ukraine & Poland \\
\hline Strongly disagree & 34.0 & 15.7 & 29.1 & 24.2 & 23.4 \\
\hline Disagree somewhat & 37.5 & 39.5 & 34.1 & 32.2 & 32.0 \\
\hline Hard to say & 16.9 & 23.6 & 19.6 & 24.6 & 19.5 \\
\hline Agree somewhat & 9.7 & 18.0 & 11.9 & 12.8 & 19.1 \\
\hline Strongly agree & 1.8 & 3.1 & 3.9 & 3.4 & 5.9 \\
\hline
\end{tabular}

Source: Own study within the State Committee for Scientific Research project, No. N N116438837

Confidence in the truthfulness of people asking in public places for financial support has been the greatest among responders from Poland, while the lowest among those from the Czech Republic. The Czechs avoid any suffering. Suffering is unwelcome, almost socially unacceptable. Generally speaking, they do not like anything what is sad, what can not be laughed at, or what should be looked to. They effectively sweep away from their surroundings all disagreeable things, afflicting elements and those which should be closely looked at. The problem of homeless people or necessitous people belongs to such unwanted topics. 
Table 5. Lecturers at my university give marks during examination being guided only by the quality of student's answer.

\begin{tabular}{|c|c|c|c|c|c|}
\hline Degree of agreement (\%) & $\begin{array}{c}\text { Czech } \\
\text { Republic }\end{array}$ & Lithuania & Russia & Ukraine & Poland \\
\hline Strongly disagree & 3.2 & 3.0 & 7.8 & 6.3 & 5.7 \\
\hline Disagree somewhat & 14.9 & 13.4 & 16.0 & 18.9 & 16.7 \\
\hline Hard to say & 32.2 & 24.5 & 25.6 & 25.1 & 24.6 \\
\hline Agree somewhat & 39.4 & 343.8 & 36.9 & 38.1 & 35.5 \\
\hline Strongly agree & 10.1 & 15.3 & 12.2 & 10.2 & 17.3 \\
\hline
\end{tabular}

Source: Own study within the State Committee for Scientific Research project, No. N N116438837

The highest percentage of responders from the Czech Republic has declared confidence in the objectivity of student evaluation by lecturers, while the least one from Ukraine. The confidence of the Czech responders may be due, like in the previous question, to a will to cross easily that stage of life. Relatively low confidence in the objectivity of lecturers in Ukraine and Russia may result from social transformations being unfavourable for them.

Table 6. Having an original idea, it is better not to share it with colleagues until it has been implemented because somebody may use it for himself / herself.

\begin{tabular}{|c|c|c|c|c|c|}
\hline Degree of agreement (\%) & $\begin{array}{c}\text { Czech } \\
\text { Republic }\end{array}$ & Lithuania & Russia & Ukraine & Poland \\
\hline Strongly disagree & 4.4 & 4.4 & 3.1 & 4.6 & 13.0 \\
\hline Disagree somewhat & 22.2 & 21.6 & 16.7 & 15.2 & 27.2 \\
\hline Hard to say & 22.3 & 28.4 & 24.0 & 27.6 & 19.5 \\
\hline Agree somewhat & 39.7 & 34.6 & 37.5 & 31.1 & 26.8 \\
\hline Strongly agree & 11.4 & 10.7 & 17.3 & 19.9 & 13.3 \\
\hline
\end{tabular}

Source: Own study within the State Committee for Scientific Research project, No. N N116438837

Confidence in the peer group and the circle of friends has been declared to the highest extent by responders in Poland, while those from Russia and Ukraine have put confidence in them with relatively extreme caution. Low confidence in the close social surroundings in these countries may result from previous many year's practices forcing the harmonious interaction in a collective. 
Table 7. It is the best when my boss at work does not know much about my personal matters.

\begin{tabular}{|c|c|c|c|c|c|}
\hline Degree of agreement (\%) & $\begin{array}{c}\text { Czech } \\
\text { Republic }\end{array}$ & Lithuania & Russia & Ukraine & Poland \\
\hline Strongly disagree & 2.7 & 1.8 & 3.3 & 3.1 & 5.3 \\
\hline Disagree somewhat & 18.3 & 15.2 & 9.2 & 10.8 & 19.2 \\
\hline Hard to say & 28.9 & 29.7 & 19.6 & 20.6 & 20.3 \\
\hline Agree somewhat & 40.3 & 39.8 & 45.6 & 40.3 & 33.8 \\
\hline Strongly agree & 9.7 & 13.4 & 21.1 & 23.7 & 21.4 \\
\hline
\end{tabular}

Source: Own study within the State Committee for Scientific Research project, No. N N116438837

The most responders from Poland and the Czech Republic have declared confidence in the boss at workplace when having personal problems, while definitely the least from Russia and Ukraine. Like in the previous question, a possible explanation of such a distribution of confidence among responders is the preferred model of functioning of employee groups, i.e. the one that favours individual achievements of employees and self-dealing with problems (including personal ones) in Poland. In the post-Soviet countries, however, there are still reminiscences of the previous economic system, favouring co-operation in an employee collective and forced confidence in superiors who had to be also an authority on personal problems.

Table 8. I rarely check weight scanner when checkout assistant weights the products being bought by me.

\begin{tabular}{|c|c|c|c|c|c|}
\hline Degree of agreement (\%) & $\begin{array}{c}\text { Czech } \\
\text { Republic }\end{array}$ & Lithuania & Russia & Ukraine & Poland \\
\hline Strongly disagree & 13.5 & 4.4 & 6.0 & 5.6 & 5.8 \\
\hline Disagree somewhat & 23.8 & 9.8 & 15.5 & 12.7 & 10.6 \\
\hline Hard to say & 8.9 & 6.1 & 11.2 & 13.9 & 8.4 \\
\hline Agree somewhat & 30.9 & 33.5 & 33.0 & 32.7 & 37.1 \\
\hline Strongly agree & 22.7 & 46.2 & 32.9 & 33.5 & 37.9 \\
\hline
\end{tabular}

Source: Own study within the State Committee for Scientific Research project, No. N N116438837

The most responders from Lithuania and Poland have declared confidence in the fairness of shop assistants, while the least from the Czech Republic. The lowest rate among the Czech responders is due to the adopted model of economic system transformation, negating liberalism and free market in favour of slow economic growth and preservation of social equality. This brings forth, as a side-effect, a limited confidence in economic and trading institutions. Dynamic development of the liberal model of capitalism, particularly in Poland, results in a relatively greater confidence in the subjects representing it. 
Table 9. Usually, I am not afraid that somebody will take advantage of me when I co-operate with people.

\begin{tabular}{|c|c|c|c|c|c|}
\hline Degree of agreement (\%) & $\begin{array}{c}\text { Czech } \\
\text { Republic }\end{array}$ & Lithuania & Russia & Ukraine & Poland \\
\hline Strongly disagree & 3.9 & 2.6 & 7.2 & 6.8 & 6.7 \\
\hline Disagree somewhat & 20.7 & 17.0 & 20.3 & 20.6 & 17.9 \\
\hline Hard to say & 22.5 & 20.7 & 25.9 & 28.3 & 18.1 \\
\hline Agree somewhat & 43.5 & 45.7 & 35.9 & 34.2 & 34.1 \\
\hline Strongly agree & 9.3 & 14.0 & 9.5 & 8.4 & 23.1 \\
\hline
\end{tabular}

Source: Own study within the State Committee for Scientific Research project, No. N N116438837

The most responders from Lithuania, Poland and the Czech republic have declared confidence in the partners co-operating with us in the public forum, while the least from Russia and Ukraine. Such a distribution of confidence rates has been substantially affected by reminiscences of the previous system, forcing co-operation in a collective, and the lack of increasing interest, in this context, in the emotional life of an individual.

Table 10. There is no room for confidence on the road to career because it may turn out at the least expected moment that somebody has been waiting for my error or mistake.

\begin{tabular}{|c|c|c|c|c|c|}
\hline Degree of agreement (\%) & $\begin{array}{c}\text { Czech } \\
\text { Republic }\end{array}$ & Lithuania & Russia & Ukraine & Poland \\
\hline Strongly disagree & 5.2 & 5.1 & 3.9 & 4.6 & 12.4 \\
\hline Disagree somewhat & 28.4 & 21.7 & 14.1 & 11.9 & 26.0 \\
\hline Hard to say & 33.8 & 34.6 & 28.9 & 31.1 & 23.9 \\
\hline Agree somewhat & 28.5 & 28.2 & 33.7 & 30.2 & 26.5 \\
\hline Strongly agree & 4.0 & 10.4 & 18.2 & 20.4 & 11.1 \\
\hline
\end{tabular}

Source: Own study within the State Committee for Scientific Research project, No. N N116438837

The most responders from Poland and the Czech Republic have declared confidence in the social surroundings when pursuing the own road to career, while the least from Russia and Ukraine. In Poland and the Czech Republic, the model of functioning of an individual, being defined as a so called Homo Sovieticus, has been discredited from the very beginning and abandoned at the earliest. In many post-Soviet countries, this model is still in force (vide Byelorussia). In other ones, it continues to have a substantial effect on the mentality of elderly people and, in part, younger generations. While the lifetime career (including professional one) is being positively perceived in Poland and the Czech Republic, it is being seen rather negatively in Russia and Ukraine [Borowski, A. 2013; Francis, J., et al., 2012; Cattell. V., et al., 2008; Goodman, B. 2013]. 


\section{CONCLUSIONS}

The cultural rules functioning in the countries under examination differently generate confidence of individuals in other people with whom they interact in public places. The rules that have required so far a priori confidence in certain people or interactions being taken every day or incidentally as a result of the social changes taking place become, partly or wholly, inadequate in a new reality. Adherence to such rules on the basis of inertia is of dysfunctional nature in the aspect of society as a whole. Definitely greater confidence is generated by the society being fully democratic, with the established traditions in this regard. The functioning of societies with resentments toward collectivism and criticising the unhampered initiative in most areas definitely decreases the level of confidence of individuals in other people and interactions with them, irrespective of causes (of choice or perforce). The study being carried out confirmed differences in the question of public confidence in people with whom we interact in public places among the students of selected countries of Central and Eastern Europe. The relatively highest level of confidence has been showed by students from the Czech Republic and Poland, while the lowest, in most questions, by those from Russia and Ukraine. However, this does not change the fact of similar differences in the question of confidence between the countries of former Communist block and those of the Western Europe.

\section{References}

[1] P. Sztompka, Studia Socjologiczne 4 (1997) 147.

[2] A. Cybulska, Zaufanie społeczne, raport CBOS BS/33/2012, 2012, p. 3.

[3] A. Borowski, International Letters of Social and Humanistic Sciences 3 (2013) 69-74.

[4] A. Borowski, International Letters of Social and Humanistic Sciences 2 (2013) 56-60.

[5] A. Borowski, International Letters of Social and Humanistic Sciences 4 (2013) 70-74.

[6] A. Borowski, International Letters of Social and Humanistic Sciences 5 (2013) 79-83.

[7] A. Borowski, International Letters of Social and Humanistic Sciences 7 (2013) 113-118.

[8] R. Staszewski, Ogólnopolski Przegląd Medyczny 7 (2009) 71-75.

[9] Oprea-Valentin Buşu, International Letters of Social and Humanistic Sciences 10(2) (2014) 156-162.

[10] Oprea-Valentin Buşu, International Letters of Social and Humanistic Sciences 12 (2014) 41-48.

[11] Peter Emerson, International Letters of Social and Humanistic Sciences 12 (2014) 90-109.

[12] Ștefan Vlăduțescu, International Letters of Social and Humanistic Sciences 10(2) (2014) 100-106.

[13] Polskie Badanie Przestępczości /VI edycja/. Wydział Analiz KGP, Warszawa 2013.

[14] Piętak P., Krótki tekst o zaufaniu, http://www.teologiapolityczna.pl/przemyslaw-pietak-krotki-tekst-o-zaufaniu

[15] M. Mularska-Kucharek, Studia Regionalna i Lokalne 2 (2011) 44. 
[16] Alexandra Iorgulescu, International Letters of Social and Humanistic Sciences 7 (2014) 14-21.

[17] Ștefan Vlăduțescu, International Letters of Social and Humanistic Sciences 7 (2014) 8-13.

[18] Raport: Badanie opinii publicznej związane z zaufaniem do wymiaru sprawiedliwości, Krajowa Rada Sadownictwa 4 (2009).

[19] H. Domański, Nauka 4 (2004) 65-98.

[20] Jason L. Powell, International Letters of Social and Humanistic Sciences 10(2) (2014) 107-120.

[21] Susanne Y. P. Choi, Roman David, American Journal of Sociology 117(4) (2012) 1172-1201.

[22] Jeffrey C. Goldfarb, American Journal of Sociology 83(4) (1978) 920-939.

[22] Amy C. Butler, Social Service Review 69(1) 1995) 1-30.

[23] A. Borowski, International Letters of Social and Humanistic Sciences 1 (2013) 14-18.

[24] A. Borowski, International Letters of Social and Humanistic Sciences, 1 (2013) 19-27.

[25] Francis, J., B. Giles-Corti, L. Wood, M. Knuiman. Journal of Environmental Psychology 32(4) (2012) 401-409.

[26] Cattell. V., N. Dines, W. Gesler, S. Curtis. Health \& Place 14(3) 2008) 544-561.

[27] Goodman B., Nurse Education Today 33(2) (2013) 81-82.

[28] Goffman E. (2012). Zachowanie w miejscach publicznych, Warszawa, s. 266-273.

[29] Goffman E. (2011). Relacje w przestrzeni publicznej, Warszawa, s. 15-45. 